\title{
The Role of Innovation Clusters in the Development of Innovative Environment
}

\author{
Roman Andrienko ${ }^{1 *}$
}

\author{
${ }^{1}$ Southern Federal University, Russia \\ *Email: romanandrienko91@gmail.com
}

\begin{abstract}
This article is devoted to assessing the role of innovation clusters in enhancing innovation activities of the state. At the present economic development stage, innovation clusters can be considered as one of the main elements of the innovation system since the strategic task of their functioning is to develop and produce innovations. The innovative potential is one of the elements of the country's competitiveness, the innovative development level of which is important in the functioning of the global economy. Based on this, it should be noted that innovation clusters are an effective tool for increasing the competitiveness level of the Russian Federation. The main indicator characterizing the importance of the functioning of innovative clusters for the development of an innovative environment are indicators of their production volume, the share of the volume of products made by innovative clusters in the total production of innovative goods and services. In this regard, in order to consider the role of innovative clusters in the development of an innovative environment, the work analyzed indicators such as the dynamics of the production volume of innovative clusters, the number of high-performance jobs in innovative clusters, the share of production of innovative clusters in the total volume of innovative products of other enterprises, and organizations.
\end{abstract}

Keywords: Innovative clusters, Points of growth, Competitiveness, Import substitution.

\section{INTRODUCTION}

The relevance of this topic is due to the fact that in modern conditions, which are characterized by a high level of global competition, special importance is attached to the formation of an effective innovation system at the national level taking into account the search for ways to adapt to the crisis phenomena of the world economy. Currently, innovation clusters are one of the factors of sustainable economic development [1], their functioning has a direct impact on the rate, level and quality of innovative development of the state. Innovative clusters have the potential to contribute to their dynamic development, effectively implement the growth point function for the regional economy, which also affects the development of the national economic system.

\section{RESEARCH METHODOLOGY}

\subsection{Problem formulation}

The modern economy has a close relationship with the innovation environment. The innovative activity level of enterprises of various subjects of the state is one of the main factors determining the level of competitiveness of the national economy as a whole. The economic development analysis in Russia and abroad allows us to assert that nowadays territorial clusters are becoming innovative platforms, on the basis of which important innovation and technological changes in the state are carried out. An effective policy for the development of innovative clusters should be aimed, first of all, at intensifying the mechanisms of innovative growth of enterprises and firms, strengthening socio-economic, scientific and educational partnerships at the national and international levels. 
The innovative component of the sphere of economic development of the Russian Federation has been considered quite fully, but further research requires the application of the developed and documented innovative strategies of the state [2] taking into account the clustering processes of the national economy, especially in the era of such global phenomena in the world economic space as a pandemic and economic sanctions.

\subsection{Review of scientific works on this issue}

Despite the fact that the problem under consideration is being studied by many authors, strengthening innovative development continues to be one of the main tasks of state policy aimed at creating a full-fledged basis for the national innovation system.

So L.V. Koch and V.S. Prosalova [3] investigates the essence of innovation activity of clusters in Russia and the principles of its implementation in her work. Researchers come to the conclusion that the development of the innovative potential of cluster associations contributes to an increase in the innovation rating of the Russian Federation and the level of the country's competitiveness in the world market.

T.A. Levchenko [4] analyzes the role of clusters in the development of the national innovation system of Russia, saying that innovation clusters being growth points of science and industry, contribute to the development of the national innovation system.

O.A. Chernova [5] defines the concepts of "innovation" and "innovative potential" highlighting a number of characteristics of the innovation process that determine the degree of readiness of an economic entity to carry out innovative activities in the integrated structure of all innovative components of the region: scientific and technical, production and technological, personnel, financial and economic ones.

It should also be especially noted the importance of the educational component in the innovative process of the development of cluster formations. In this regard, a significant study is the work of A. Yu. Nikitaeva [6], who examines the institutional structure of the region in the context of innovative industrial development.

The importance of scientific potential for the development of the innovation economy is also considered in the works of a number of researchers, such as S.A. Tumenova [7], O.Yu. Kirillova and T.S. Kopycheva [8].

G.A. Yasheva and E.A. Kostyuchenko [9] focus their attention on the methodological aspects of the cluster approach to innovative development and increasing the competitiveness of the national economy. The authors put forward the idea of using a cluster approach based on the implementation of network cooperation and public- private partnership in addition to the traditional approaches to the development of an innovation system.

Russian [10] and foreign [11] researchers also note an important role in choosing a model of integrated innovative development not only of individual enterprises and industries, but also of the system of relationships between suppliers, consumers, research and educational institutions, and public institutions.

From the point of view of such researchers as A.A. Sozinova, O.I. Okhrimenko, L.V. Goloshchapova, E.P Kolpak, N.B. Golovanova, E.A. Tikhomirov the basis of successful development of industrial and innovation clusters is "a symbiosis of cooperation and competition, taking into account the positive synergy effects of territorial agglomeration" [10, p. 111]. According to the authors, "interrelated business entities on the basis of sustainable partnerships can have a potential that exceeds the simple sum of their capabilities" [10].

The authors of "Differences in creating product innovations versus process innovations across European industries" G.V. Matthias, R.B. Mellor, noting the role of the institutional factor as significant in the implementation of innovative activities, taking into account the "social context" [11, p. 77] consider that "institutional quality exhibits mediate effects through financing of $R \& D$ and the design of the organizational structure, with larger technical / R\&D departments being found in firms in environments of high societal quality" [11, p.59]. This point of view is relevant for the successful development of innovative activities in the opinion of many researchers.

\section{ANALYSIS OF THE DEVELOPMENT OF INNOVATION CLUSTERS IN THE RUSSIAN FEDERATION}

Currently, there are 41 innovation clusters in the Russian Federation. The geography of the location of innovation clusters is very wide: cluster associations that carry out innovative activities are concentrated in all districts of the Russian Federation.

Functioning innovation clusters have a different level of development, which depends on many factors, in particular, on the economic and innovation potential of the territory where the clusters are located. As statistics show, 23 innovation clusters are at the initial development level, 8 clusters have average development indicators, and 10 clusters have a high development level [12].

The main indicator characterizing the activity of innovation clusters is the volume of production [14].

Figure 1 shows that the volume of production of innovative clusters in the Russian Federation has a positive trend. The growth of the indicator under review in 2018 compared to 2017 was $21 \%$, and in 2019 
compared to 2018 it was $25 \%$. The total increase in the volume of production of innovative clusters for the period under review is $52 \%$. The positive dynamics of the increase in the growth rates of this indicator testifies to the effective increase in production rates.

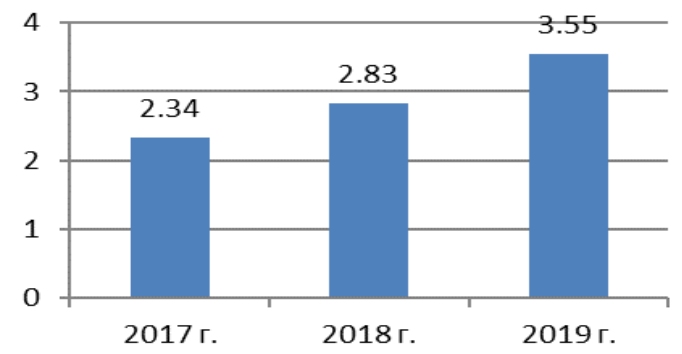

Figure 1 The volume of production of innovative clusters (trillion rubles) [12].

To implement the innovative activities of clusters, high-performance workplaces are required, which contribute to the improvement of quantitative and qualitative indicators of labor productivity.

Figure 2 reflects the dynamics of the number of highperformance workplaces in innovation clusters of the Russian Federation.

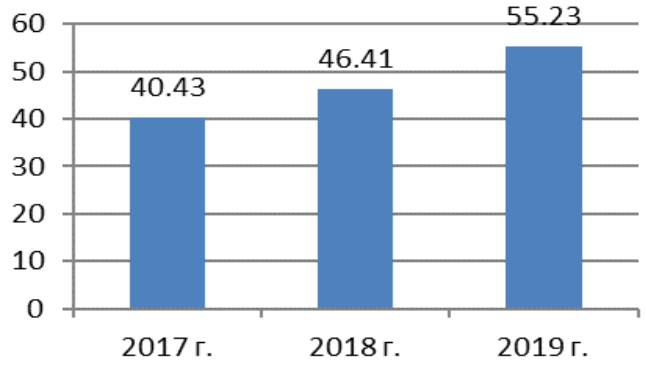

Figure 2 The number of high-performance workplaces in innovation clusters (thousand units) [12].

Figure 2 shows that the dynamics of the number of high-performance workplaces in innovation clusters throughout the entire period under review is positive. The overall increase in this indicator for the entire period was $37 \%$. This fact is a positive trend in the development of both separate innovation clusters and the innovation environment as a whole. In relation to the development of the innovation system, this is primarily due to the fact that the functioning of high-performance workplaces contributes to the possible implementation of high-tech production and innovative methods of production activity, the use of which is characterized by the achievement of a higher level of effective quantitative and qualitative indicators compared to traditional production methods. In addition, the use of highly productive workplaces by workers requires them to have a high level of qualifications, which contributes to the improvement of the quality characteristics of the national workforce.

\section{EVALUATION OF THE IMPACT OF THE INNOVATION CLUSTER ACTIVITY ON THE DEVELOPMENT OF THE INNOVATION ENVIRONMENT}

Currently, the main concentration sectors of innovation clusters are information technology, biotechnology and pharmaceuticals, and new materials.

In the field of information technologies, innovation clusters have an impact on the development of the innovation system through the implementation of the following activities:

- development of complex IT solutions in the field of electronic and information society;

- software reengineering and implementation of automated control systems;

- application of innovative solutions in the field of information security.

The implementation of the above listed activities contributes to the progressive development of the innovation environment since the clusters create innovative products and develop innovative methods of management and use of information technologies.

Within the biotechnology industry, innovation clusters, in particular, are engaged in the development of innovative pharmaceutical products. Currently, the main activities of innovative clusters functioning in the biotechnology and pharmaceutical industries are:

- production of new pharmaceutical products;

- creation of unique pharmaceutical products for various fields of medicine;

- development and research.

The activity of clusters in this industry direction, in particular, is of a patent nature, which has a positive effect on the indicators of innovative development of both regions and the country as a whole. In addition, the functioning of innovative clusters in the biotechnological and pharmaceutical industries reduces dependence on the pharmaceutical external market and contributes to the effective development of the import substitution process since in the process of their activity new medical products are produced and introduced to the domestic market.

In addition to influencing the development of the innovation environment, the functioning of innovation clusters has an impact on increasing the living standard of the population.

The making of innovative clusters within such an industry area as new materials has an impact on the development of other sectors, in particular industry.

The creation of new materials contributes to the effective development of production processes in the 
country since their use leads to a reduction in production costs, improving the quality of products, increasing the range of manufactured goods and services.

It is also worth noting that, first of all, the functioning of innovation clusters has an impact on the volume of innovative products produced.

Figure 3 shows the change in indicators of the volume of innovative products made by innovation clusters in the total volume of innovative products of other organizations.

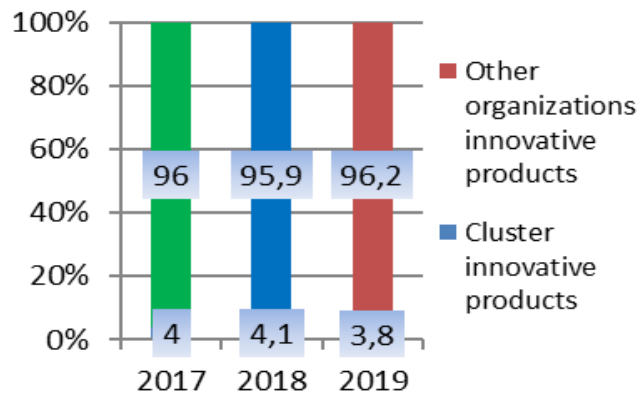

Figure 3 Indicators of the volume of innovative products of clusters in the total volume of innovative products of other organizations $(\%)$ [12].

Figure 3 shows that about $4 \%$ of the total volume of innovative goods, works and services is produced by innovative clusters. The dynamics of this indicator has a stick-slip nature since it depends on the number and volume of production of other innovation-oriented organizations.

In addition, the impact of the functioning of innovation clusters is confirmed by the relationship of the number of innovation clusters, information economy and innovation development indices. These indicators are presented in table 1 .

Table 1 shows the direct relationship of the indicators considered in it: with an increase in the number of innovative clusters functioning in the country, the values of the information economy and innovative development indices increase, which has a positive effect on strengthening the competitiveness of the Russian Federation, which is important in the global economy.
The indexes inherent in the Russian Federation presented in the table are significantly lower than those of Sweden: the information economy index is 9.43 , and the innovation development index has a value of 62.5 .

Currently, the main indicator reflecting the competitiveness level of the state is the global competitiveness index, which, when calculating, along with such indicators as macroeconomic stability, the efficiency of labor markets, finance, goods and services, the level of technological development, takes into account the innovative potential of the state.

Today, the Russian Federation ranks 43rd out of 141st in the global competitiveness index in the world ranking with the value of the same index equal to 66.7. The leading positions in this rating are taken by Singapore, which has a global competitiveness index equal to 84.8; the second place is taken by the United States with a value of this index equal to 83.7; the third place is taken by Hong Kong with a global competitiveness index of 83.1. At the same time, a much larger number of innovation clusters operate in these countries, the number of which exceeds 200. Based on this, we can say that the Russian Federation has a significant lag behind the developed countries of the world, possessing an average level of competitiveness.

\section{CONCLUSION}

As mentioned above, innovation potential is one of the components of a country's competitiveness. The analysis carried out in the work has showed that the level of competitiveness of the Russian Federation has average values. To improve a country's position in the functioning of the global economy, an increase in this indicator is required.

Since at the present stage of economic development, innovation clusters are the main points of growth in the development of the innovation system, it is necessary to increase the efficiency of their functioning. To achieve this goal, the following activities are offered:

- strengthening the interregional integration by merging innovative cluster associations located in different regions will increase the production and innovation potential of innovation clusters, which will

Table 1. The relationship of the number of clusters with the indexes of information development and the index of innovative development [13]

\begin{tabular}{|l|c|c|c|}
\hline Year & $\begin{array}{c}\text { The amount of innovation } \\
\text { clusters }\end{array}$ & $\begin{array}{c}\text { The index of informational } \\
\text { economy }\end{array}$ & $\begin{array}{c}\text { The index of innovative } \\
\text { development }\end{array}$ \\
\hline 2017 & 33 & 4.87 & 24.1 \\
\hline 2018 & 39 & 5.31 & 29.4 \\
\hline 2019 & 41 & 5.78 & 35.6 \\
\hline
\end{tabular}


have a positive impact on the development of the national innovation system;

- supporting the development of cooperation and subcontracting by providing clusters with subsidies for the implementation of joint projects will strengthen the innovation component of enterprises;

- the development of public and private partnerships will contribute to an increase in the degree of interdependence between the subjects of the business environment and the state, which, in particular, will lead to an increase in the volume of financial resources aimed at the development of innovation clusters;

- internationalization of innovation cluster activities will allow domestic clusters to gain access to foreign methods of cluster activities, as well as expand sales markets.

Summing up the functioning impact analysis of innovative clusters on the development of the innovation environment, it should be noted that currently clusters are intensive drivers of scientific and technological progress, the development of innovation and economic systems, therefore, it is significant to strengthen the development potential of innovative cluster formations. This is due primarily to the fact that innovative cluster formations are one of the main producers of innovations. It is the cluster associations that are engaged in the development of innovative production methods, they are the manufacturers of the latest technologies, as well as the high-tech production implementers. All of the above contributes to an increase in the qualitative and quantitative indicators of the development in the field of innovation. Based on this, it should be drawn that innovation clusters have an important role in the innovation environment development.

\section{REFERENCES}

[1] R.V. Andrienko, Innovation Cluster Development As A Factor For Sustainable Regional Economic Growth, The European Proceedings of Social and Behavioural Sciences, EpSBS, International Conference on Economic and Social Trends for Sustainability of Modern Society (ICEST 2020), 2020, pp. 662-670. DOI: https://doi.org/10.15405/epsbs.2020.10.03.77

[2] Forecast of long-term socio-economic development of the Russian Federation for the period up to 2030, Retrieved

from: http://www.consultant.ru/document/cons_doc_LA W_144190/

[3] L.V. Koch, V.S. Prosalova, Innovative activity of clusters in Russia and principles of its implementation, Bulletin of the Transbaikal State University 4 (2017) 102-104.
[4] T.A. Levchenko, Clusters and Their Role in the Development of the National Innovation System of Russia, Azimuth of Scientific Research: Economics and Management 3 (2017) 239-243.

[5] O.A. Chernova, Content of innovation processes in the context of regional development, Bulletin of Tomsk State University (316) (2008) 155-160.

[6] A.Yu Nikitaeva, Institutional structure of the region in the context of innovative industrial development, Journal of Institutional Studies Vol. 9 Iss. 1 (2017) 134-149. DOI: https://doi.org/10.17835/2076$\underline{6297.2017 .9 .1 .134-149}$

[7] S.A. Tumenova, Regional Competitiveness: The Search for Effective Solutions in the Field of Innovative Development, Proceedings of the International Scientific Conference "Far East Con" (ISCFEC 2020), Atlantis Press, 2020, pp. 2573 $2579 . \quad$ Retrieved from: https://doi.org/10.2991/aebmr.k.200312.361

[8] O.Yu. Kirillova, T.S. Kopycheva, Strategy Basis for the Development of Scientific Potential in the Innovative Economy of the Russian Federation, International Scientific Conference "Far East Con" (ISCFEC 2020), 2020, pp. 3016-3023. DOI: https://doi.org/10.2991/aebmr.k.200312.431

[9] G.A. Yasheva, E.A. Kostyuchenko, Methodological aspects of the cluster approach to innovative development and increasing the competitiveness of the national economy, Bulletin of the Voronezh State Technical University, Iss. 1(30), 2016.

[10] A.A. Sozinova, O.I. Okhrimenko, L.V. Goloshchapova, E.P Kolpak, N.B. Golovanova, E.A. Tikhomirov, Industrial and innovation clusters: Development in Russia, International Journal of Applied Business and Economic Research 15(11) (2017) 111-118. Retrieved from: http://www.scopus.com/inward/record.url?scp=850 21742790\&partnerID=8YFLogxK

[11] G.V. Matthias, R.B. Mellor, Differences in creating product innovations versus process innovations across European industries, International Journal of Innovation and Regional Development Vol. 9 Iss. 1 (2019) 59-79. DOI: https://doi.org/10.1504/IJIRD.2019.102622

[12] Cluster Map of Russia, Russian Cluster Observatory, Institute for Statistical Studies and Economics of Knowledge, National Research Institute "Higher School of Economics" 2019. Retrieved from: https://map.cluster.hse.ru/ 
[13] Humanitarian portal. Retrieved from: https://gtmarket.ru/ratings/global-competitivenessindex

[14] M. Castells, 1996, The Informational City: Economic Restructuring and Urban Development, The Wiley-Blackwell and Castels Manulal, 2010. Retrieved from: https://deterritorialinvestigations.files.wordpress.co $\mathrm{m} / 2015 / 03 / \mathrm{manuel}$ castells the rise of the netwo rk_societybookfi-org.pdf 